\title{
Expanding Role of Endovascular Repair for Type B Aortic Dissection
}

\author{
Sanjiv Sharma ${ }^{1}$ Arun Sharma ${ }^{1}$ \\ ${ }^{1}$ Department of Cardiovascular Radiology and Endovascular \\ Interventions, All India Institute of Medical Sciences, \\ New Delhi, India \\ J Clin Interv Radiol ISVIR 2017;1:89-95.
}

\begin{abstract}
Address for correspondence Sanjiv Sharma, MD, Department of Cardiovascular Radiology and Endovascular Interventions, All India Institute of Medical Sciences, New Delhi, India (e-mail: meetisv@yahoo.com).
\end{abstract}

\begin{abstract}
Aortic dissection is a medical emergency that can quickly lead to death, despite optimal treatment. The Stanford classification is widely used and is in close relationship to clinical practice, as type $A$ dissections require primary surgical repair whereas type $B$ dissections are treated medically as initial treatment with surgery or endovascular repair (EVR) reserved for any complications. Multislice CT is the investigation of choice to establish the diagnosis and plan treatment strategies. Therapeutic strategies differ for treatment of an acute dissection compared with a chronic dissection. Traditionally, most institutions favor a "complication specific" approach for type B dissection with antihypertensive treatment and use of $\beta$-blockers as primary therapy. Surgery or EVR is reserved for patients with recurrent pain, life-threatening complications, or rapid aortic expansion. With above algorithms, there is evidence that 30 to $50 \%$ patients on conservative therapy develop serious morbidity or mortality over 5 -year period. Clinical and imaging markers of adverse outcome are being identified to revise the management strategies and offer EVR to those at risk for adverse outcome. This is especially relevant in view of the fact that EVR for type B dissection is associated with procedural success in $99.2 \pm 0.1 \%$ patients. Overall survival rates of $96.9 \%$ at 30 days, $96.7 \%$ at

Keywords

- aortic dissection

- endovascular repair

- surgery

- type B dissection 6 months, $96.4 \%$ at 1 year, $95.6 \%$ at 2 years, and $95.2 \%$ at 5 years are reported after EVR in type B dissections. There is emerging evidence that EVR may be noninferior to surgery in this group of patients. These observations along with the development of dissection-specific device designs have the potential to rewrite the management algorithms for type B aortic dissection and define the role of EVR in this disease.
\end{abstract}

\section{Introduction}

Aortic dissection (AD) is characterized by a tear in the intima that allows pulsatile blood to penetrate the vessel wall. The entry tear is commonly located within the first $2 \mathrm{~cm}$ of the ascending aorta or at the isthmus of the aorta just beyond the ligamentum arteriosum as these regions are subjected to the greatest hemodynamic stress. Moreover, tears at these locations are more likely to be transverse in orientation rather than longitudinal. The dissection may propagate in an ante- or retrograde direction or in both directions. ${ }^{1-3}$ It is one of the most catastrophic events that can affect the aorta and is one of the two conditions in which the aorta grows very rapidly over a short time. ${ }^{1,4}$ The mortality rate in patients with untreated acute $\mathrm{AD}$ increases by $1 \% / \mathrm{h}$, with $13 \%$ of patients dying by 12 hours, $21 \%$ by 24 hours, and approximately $80 \%$ are dead within 2 weeks, if untreated and located in the ascending aorta. ${ }^{1-5}$ It is approximately two to three times more common than a ruptured abdominal aortic aneurysm.

\section{Classification Systems}

Various methods have been used to describe ADs. The systems commonly in use are based on either the anatomy 
Table 1 Svensson classification

\begin{tabular}{l}
\hline Class 1: Classic dissection with true and false lumen \\
\hline Class 2: Intramural hematoma or hemorrhage \\
\hline Class 3: Subtle dissection without hematoma \\
\hline Class 4: Atherosclerotic penetrating ulcer \\
\hline Class 5: latrogenic or traumatic dissection \\
\hline
\end{tabular}

of the dissection or the duration of onset of symptoms prior to presentation. ${ }^{6}$ The Stanford classification divides dissections into two types depending on whether the ascending aorta is involved: type $\mathrm{A}$ involves the ascending aorta whereas type $B$ involves the descending aorta distal to the left subclavian artery. The DeBakey classification divides dissections into three types based on where the original intimal tear is located and the extent of the dissection:

- Type I involves the ascending aorta, aortic arch, and descending aorta.

- Type II is confined to the ascending aorta.

- Type III is confined to the descending aorta distal to the left subclavian artery.

Type III dissections are further divided into IIIa and IIIb: type IIIa refers to dissections that originate distal to the left subclavian artery but extend proximally and/or distally, mostly above the diaphragm; and type IIIb refers to dissections that originate distal to the left subclavian artery, extend only distally, and may extend below the diaphragm. Svensson classification is more etiology and image morphology based, and it divides this group of abnormalities into five classes (-Table $\mathbf{1}$ ).

The Stanford classification is in close relationship to clinical practice, as type A dissections require primary surgical repair whereas type $B$ dissections are treated medically as initial treatment with surgery or EVR reserved for any complications.

Typically, AD is seen in the 50- to 70-year age group and is twice as common in men. Nearly 72 to $80 \%$ patients have associated hypertension. Connective tissue disorders, vasculitis, trauma, bicuspid aortic valve, and tertiary syphilis are among other less common causes of $\mathrm{AD}$ ( - Table 2 ). In young

Table 2 Causes of aortic dissection

\begin{tabular}{|l|}
\hline $\begin{array}{l}\text { Hypertension: 72-80\% patients have associated } \\
\text { hypertension }\end{array}$ \\
\hline Connective tissue disorders \\
\hline $\begin{array}{l}\text { Marfan's syndrome, Turner's syndrome, pseudoxanthoma } \\
\text { elasticum }\end{array}$ \\
\hline Vasculitis \\
\hline Trauma: accidental or iatrogenic \\
\hline $\begin{array}{l}\text { Late sequelae of cardiac surgery, esp. after aortic valve } \\
\text { replacement for aortic regurgitation }\end{array}$ \\
\hline Bicuspid aortic valve \\
\hline Tertiary syphilis \\
\hline
\end{tabular}

women, over one-half of the cases are seen during pregnancy, typically in the third trimester or in the postpartum period. ${ }^{7}$ Type B dissection accounts for approximately $40 \%$ of all dissections and typically occurs in the morning period, more commonly in winters. ${ }^{8}$ The clinical diagnosis is often difficult to establish as the symptoms can mimic a variety of diseases, including myocardial infarction and pericarditis, among others.

\section{Imaging}

Some form of imaging is usually necessary to establish the diagnosis, define the extent of dissection and involvement of branch vessels, and identify the complications. The selection of the imaging technique is usually based on the pretest likelihood of the diagnosis, availability of the testing modality, patient stability, and sensitivity and specificity of the test. Multislice computed tomography (CT) is fast emerging as the investigation of choice to establish the diagnosis and plan treatment strategies in $\mathrm{AD}^{9,10}$ It is preferred over other imaging techniques due to its speed, reproducibility, high spatial and contrast resolution, and its orthogonal potential (ability to provide the best anatomic plane for sizing of proximal and distal neck and landing zones). However, two issues, including the radiation dose and its potential for nephrotoxicity, should be kept in mind while using this technique as these patients will often need a catheter angiography and endovascular treatment in the immediate period and many imaging studies during follow up. Usually, a dual-phase CT angiography (CTA) is recommended in the preoperative evaluation. A typical protocol should include imaging before and after administration of contrast in the arterial phase. Imaging in postcontrast delayed phase is not always required in the preoperative period but must always be done in the follow-up after endovascular treatment to detect the endoleaks. Magnetic resonance imaging (MRI) can also be used for establishing the diagnosis, but it is less reliable in terms of measurements for device sizing for endovascular repair (EVR). We use duplex ultrasound for the evaluation and measurement of the access vessels in the groin.

The following pertinent issues must be kept in mind during imaging interpretation before deciding upon optimal treatment strategy: influence of inherent level of resolution of current imaging technologies on size assessment, the relevance of inclusion or exclusion of the aortic wall in the measurement of the device and sac size, the limitations of specific imaging modalities in terms of profiling the various anatomic segments of the aorta, the influence of geometric complexity of the aorta on the diagnosis and device sizing, the accuracy of comparison of serial images showing 1- to 2-mm change in size over two studies, changes in the shape of the aorta as a marker of disease, the detection of disease activity and its influence on the sac diameters, variations in the aortic diameter during systole and diastole and their impact on size measurements, and factoring in the body surface area while relating aortic size to the hinge points. ${ }^{6,9-11}$ 
The CT images should be analyzed to identify the length of the normal aortic tissue above and below the false channel aneurysm (at least $1.5-2 \mathrm{~cm}$ length of normal aorta devoid of any branches above and below the intended site of device delivery should be available for EVR to succeed), the relation of the dissection and false channel aneurysm to the branch vessels, obstructions of the aortic branch vessels (fixed vs. dynamic), and the amount of calcium and thrombus in the diseased segment. At least one common iliac artery should be preferably free of dissection for use as the access vessel for successful EVR. It is also important to ensure that adequate diameter vascular access (external iliac or common femoral artery of $>7.5 \mathrm{~mm}$ diameter) free of dissection, extreme tortuosity, extensive calcification, and obstructive disease is available for device delivery.

\section{Treatment}

In an acute dissection (within the first 2 weeks of the appearance of symptoms), the treatment choice depends on its location. For Stanford type A dissection, surgical management is preferred. For uncomplicated Stanford type $B$ dissections, medical management is preferred in the initial period. The risk of death due to dissection is highest in the first few hours after the dissection begins and decreases afterward. As a result, the therapeutic strategies differ for treatment of an acute dissection compared with a chronic dissection. If the patient survives this period, the prognosis is improved. Approximately, two-thirds of all dissections present in the acute phase. ${ }^{12}$ The patients who present 2 weeks after the onset of dissection are said to have chronic ADs. These individuals have been self-selected as survivors of the acute episode and can be treated with medical therapy as long as they are stable and free of complications. Complicated type $B$ dissections can be treated by surgery or EVR. ${ }^{13-18}$

EVR for type B dissection was first described by Dake et al in $1994 .^{19}$ The basic purpose of using stent grafts is to completely cover the primary entry tear and eliminate most of the inflow to the false lumen, thus promoting thrombosis of the false lumen. The graft serves to exclude flow through the initial tear in the intima and redirect aortic blood flow exclusively into the true lumen, reestablishing perfusion of aortic branches affected by the spreading dissection. This can also avoid a true lumen collapse. Procedural success during EVR for type B AD is reported in $99.2 \pm 0.1 \%$ of patients. ${ }^{20}$ In one large recent meta-analysis, major complications were reported in $3.4 \pm 0.1 \%$ patients, with the most severe neurologic complications in $0.6 \%$ patients. ${ }^{20}$ Periprocedural stroke was encountered more frequently than paraplegia ( 0.2 vs. $0 \%$ ). The overall 30 -day mortality was $2.6 \pm 0.1 \%$. In addition, $1.5 \pm 0.1 \%$ of the patients died over a mean follow-up period of $27.1 \pm 17.5$ months. Life-table analysis yielded overall survival rates of $96.9 \%$ at 30 days, $96.7 \%$ at 6 months, $96.4 \%$ at 1 year, $95.6 \%$ at 2 years, and $95.2 \%$ at 5 years. ${ }^{20}$

The concept of EVR was also propelled by the desire to induce aortic remodeling by sealing the proximal entry tear, at the same time avoiding the risks associated with open surgery. This rationale was originally based on the clinical observation that patients with spontaneous thrombosis of the false lumen have a better long-term prognosis than those without. Conversely, persistent perfusion of the false lumen has been identified as an independent predictor of progressive aortic enlargement and adverse long-term outcome. Nevertheless, spontaneous thrombosis of the false lumen is a rare observation ( $<4 \%$ of patients) and most often requires interventions to exclude it from the true lumen. It is unclear whether thrombosis of the false lumen and stabilization of the aortic diameter translates into long-term prevention of aortic rupture.

With better understanding of follow-up outcomes of medical therapy in type B dissection, it is emerging that nearly $50 \%$ of patients who are discharged from hospitals after medical treatment present with complications in the following years, and the mortality in 3 to 5 years can reach 20 to $50 \%$, respectively. ${ }^{3,21}$ Moreover, the surgical treatment of aortic complications after medical therapy also carries high mortality. In this setting, EVR has evolved as a promising option, providing a less invasive alternative treatment for type B AD. Studies have shown a mortality rate of $<10 \%$ and $>80 \%$ success rate of occlusion and thrombosis of the false lumen with EVR. ${ }^{22}$ The establishment of the International Registry of Acute Aortic Dissection (IRAD) in 1996, which gathers information from 24 centers in 11 countries, has helped in the development of an understanding of the complexity of $\mathrm{AD} .^{3}$ At present, the AD-referral centers routinely advocate EVR for complicated type B dissection, as acceptable early and midterm results have shown that there is adequate prevention of aneurysm rupture. ${ }^{23-26}$

Better understanding of clinical and imaging markers has helped identify patients with uncomplicated type B dissection who are at increased risk for worse prognosis and may benefit from an early endovascular or surgical repair. In the setting of type B dissection, clinical markers (-Table 3 ) such as recurrent and refractory pain, refractory hypertension, age $>60$ years, white race, Marfan's syndrome, and

Table 3 Clinical and radiologic markers of adverse outcome in type $\mathrm{B}$ aortic dissection

\begin{tabular}{|l|l|}
\hline Clinical/Laboratory & Radiologic \\
\hline $\begin{array}{l}\text { Recurrent and refractory } \\
\text { pain }\end{array}$ & Total aortic diameter $>44 \mathrm{~mm}$ \\
\hline Refractory hypertension & $\begin{array}{l}\text { Absolute FL diameter }>22 \mathrm{~mm} \\
\text { (100\% sensitive, } 76 \% \text { specific })\end{array}$ \\
\hline Age $>60$ y & $\begin{array}{l}\text { Cross-sectional area of FL/total } \\
\text { lumen }>0.7\end{array}$ \\
\hline White race & Width of entry tear $>10 \mathrm{~mm}$ \\
\hline Marfan's syndrome & $\begin{array}{l}\text { Location of primary entry tear- } \\
\text { under surface of arch or medial }\end{array}$ \\
\hline $\begin{array}{l}\text { Fibrinogen-fibrin degra- } \\
\text { dation product level of } \\
20 \text { mg/mL at admission }\end{array}$ & $\begin{array}{l}\text { Elliptical shape of TL in combi- } \\
\text { nation with circular FL/spiral } \\
\text { configuration of dissection flap }\end{array}$ \\
\hline
\end{tabular}

Abbreviations: FL, false lumen; TL, true lumen. 
Table 4 Complicated type B aortic dissection

\begin{tabular}{|l|}
\hline Rupture-free/contained \\
\hline Malperfusion-impending organ failure \\
\hline $\begin{array}{l}\text { Hypertension when associated with malperfusion or } \\
\text { persistent despite full medical therapy }\end{array}$ \\
\hline Increase in periaortic hematoma \\
\hline $\begin{array}{l}\text { Hemorrhagic pleural effusion in two CTs s/o impending } \\
\text { rupture }\end{array}$ \\
\hline Refractory pain-may be indicative of malperfusion \\
\hline
\end{tabular}

Abbreviation: $\mathrm{CT}$, computed tomography.

fibrinogen-fibrin degradation product level of $20 \mathrm{mg} / \mathrm{mL}$ at admission are associated with an adverse outcome. ${ }^{27-31}$ Moreover, several imaging markers can also be used to identify high-risk patients. These may include an aortic diameter of $>44 \mathrm{~mm}$ at diagnosis, partial false lumen thrombosis, false lumen diameter of $>22 \mathrm{~mm}$ (100\% sensitive, 76\% specific), location of primary entry tear on the under surface of the arch or on its medial aspect, width of entry tear $>10 \mathrm{~mm}$, elliptical shape of true lumen, circular false lumen, crosssectional area of false lumen to true lumen of $>0.7$, and a spiral configuration of the dissection ( - Table 3$)^{32-37}$

Dissection is classified as complicated (-Table 4 ) if it is associated with refractory pain; malperfusion; rupture, free, or contained; hypertension that is associated with malperfusion or persistent despite full medical therapy; increase in periaortic hematoma; and hemorrhagic pleural effusion in two CT examinations, suggesting an impending rupture. ${ }^{38,39}$ Moreover, refractory pain and persistent hypertension are associated with an increased mortality. ${ }^{40}$

The EUROSTAR (EUROpean collaborators on Stent/graft Techniques for aortic Aneurysm Repair) registry in 2004 described the first large case series of patients treated with
EVR and demonstrated primary technical success of 89\%, 30day mortality of $6.5 \%, 1$-year survival of $90 \%$, and paraplegia in $0.8 \%{ }^{41}$

Fattori et al published data from 1995 to 2012 from the IRAD in which 1,129 consecutive patients with type $B$ acute AD were monitored. ${ }^{42}$ Uncomplicated patients were medically treated (75.6\%) and those with complicated dissection were indicated for EVR (24.4\%). The hospital mortality between the two groups was similar, but at a 5-year follow-up the group that underwent EVR had a lower mortality of $15.5 \%$ compared with $29 \%$ in patients who were medically treated. Moreover, conclusions drawn from other studies also suggested that EVR is safe, effective, and improves aortic remodeling in suitable patients with type $B$ dissection (-Tables 5, 6). ${ }^{43-45}$

INSTEAD (INvestigation of STEnt Grafts in Aortic Dissection) XL trial showed that EVR in addition to optimal medical treatment is associated with improved 5-year aorta-specific survival and delayed disease progression and suggested that EVR should be considered in stable type B dissection with suitable anatomy to improve late outcome. ${ }^{24}$ Recently, ADSORB (Acute Dissection: Stent graft OR Best medical therapy) trial compared the outcomes of a group of patients with uncomplicated dissection randomized to either best medical treatment or best medical therapy with EVR. The results suggested that the remodeling with thrombosis of the false lumen and reduction in its diameter is induced by EVR, concluding that EVR may be a safe alternative to treat acute uncomplicated dissection. ${ }^{46}$

VIRTUE registry described the mid-term clinical and morphologic results of EVR in patients with type B dissection. Findings suggested similar aortic remodeling in subacute stages as in the acute group. This retention of aortic plasticity in the subacute group further lengthens the therapeutic window for the treatment of uncomplicated type $B$ dissection. $^{47}$

Table 5 Comparison of TEVAR versus medical therapy in type B aortic dissection

\begin{tabular}{|c|c|c|c|c|c|c|c|}
\hline Author (y) & $\begin{array}{l}\text { No. of } \\
\text { patients }\end{array}$ & Subclassification & $\begin{array}{l}\text { Early } \\
\text { mortality } \\
(\%)\end{array}$ & $\begin{array}{l}\text { Early CVA } \\
n(\%)\end{array}$ & $\begin{array}{l}\text { Early SCI } \\
n(\%)\end{array}$ & $\begin{array}{l}\text { Mean } \\
\text { follow-up } \\
\text { (mo) }\end{array}$ & $\begin{array}{l}\text { Survival } \\
\text { rate (\%) }\end{array}$ \\
\hline $\begin{array}{l}\text { Fattori et al, IRAD } \\
\text { TEVAR (2008) }\end{array}$ & 43 & $\begin{array}{l}\text { Acute } \\
\text { complicated }\end{array}$ & 11.6 & \multicolumn{2}{|c|}{ NA $1(2.3)$} & 2.3 y median & $\begin{array}{l}\text { On } 27 \text { patients } \\
1 \mathrm{y}(88.9) \\
3 \mathrm{y}(76.2)\end{array}$ \\
\hline $\begin{array}{l}\text { Fattori et al, IRAD } 39 \\
\text { Medical (2008) }\end{array}$ & 390 & Acute & 8.7 & \multicolumn{2}{|c|}{ NA } & 2.3 y median & $\begin{array}{l}\text { On } 189 \text { patients } \\
1 \text { y }(90.3) \\
3 \text { y }(77.6)\end{array}$ \\
\hline $\begin{array}{l}\text { Garbade et al, } \\
\text { TEVAR (2010) }\end{array}$ & 46 & $\begin{array}{l}27 \text { acute compli- } \\
\text { cated } \\
19 \text { acute } \\
\text { uncomplicated }\end{array}$ & 19.6 & \multicolumn{2}{|c|}{$11(23.9)$} & $1,107 d$ & $\begin{array}{l}1 \text { y }(80) \\
3 \text { y }(73.3) \\
5 \text { y }(56.3)\end{array}$ \\
\hline $\begin{array}{l}\text { Garbade et al, } \\
\text { Medical (2010) }\end{array}$ & 84 & $\begin{array}{l}63 \text { acute uncom- } \\
\text { plicated } \\
21 \text { acute } \\
\text { complicated }\end{array}$ & 8.3 & \multicolumn{2}{|c|}{$12(14.3)$} & $1,107 \mathrm{~d}$ & $\begin{array}{l}1 \text { y }(86.2) \\
3 \text { y }(80.9) \\
5 \text { y }(72.1)\end{array}$ \\
\hline
\end{tabular}

Abbreviations: CVA, cerebrovascular accidents; IRAD, international registry of acute aortic dissection; NA, not available; SCI, spinal cord ischemia; TEVAR, thoracic endovascular aortic repair. 
Table 6 Comparison of TEVAR versus open surgery in type B aortic dissection

\begin{tabular}{|c|c|c|c|c|c|c|c|}
\hline Author $(y)$ & $\begin{array}{l}\text { No. of } \\
\text { patients }\end{array}$ & Subclassification & $\begin{array}{l}\text { Early } \\
\text { mortality } \\
n(\%)\end{array}$ & $\begin{array}{l}\text { Early CVA } \\
n(\%)\end{array}$ & $\begin{array}{l}\text { Early SCI } \\
n(\%)\end{array}$ & $\begin{array}{l}\text { Mean } \\
\text { follow-up } \\
\text { (mo) }\end{array}$ & $\begin{array}{l}\text { Survival } \\
\text { rate (\%) }\end{array}$ \\
\hline $\begin{array}{l}\text { Fattori et al, }{ }^{39} \\
\text { TEVAR (2008) }\end{array}$ & 43 & Acute complicated & $5(11.6)$ & NA & $1(2.3)$ & 2.3 y median & $\begin{array}{l}>29 \text { patients: } \\
1 \mathrm{y}(88.9) \\
3 \mathrm{y}(76.2)\end{array}$ \\
\hline $\begin{array}{l}\text { Fattori et al, }{ }^{39} \\
\text { Open (2008) }\end{array}$ & 59 & Acute complicated & $20(33.9)$ & $4(6.8)$ & $3(5.1)$ & NA & NA \\
\hline $\begin{array}{l}\text { Zeeshan et al, } \\
\text { TEVAR (2010) }\end{array}$ & 45 & Acute complicated & $2(4.4)$ & $3(6.7)$ & $6(13.3)$ & $37(2 \mathrm{mo}-7 \mathrm{y})$ & $\begin{array}{l}1 \mathrm{y}(82) \\
5 \mathrm{y}(79)\end{array}$ \\
\hline $\begin{array}{l}\text { Zeeshan et al, }{ }^{43} \\
\text { Open (2010) }\end{array}$ & 20 & Acute complicated & $8(40.0)$ & 0 & $2(10)$ & $37(2 \mathrm{mo}-7 \mathrm{y})$ & $\begin{array}{l}1 \mathrm{y}(58) \\
3 \mathrm{y}(52) \\
5 \mathrm{y}(44)\end{array}$ \\
\hline
\end{tabular}

Abbreviations: CVA, cerebrovascular accidents; NA, not available; SCI, spinal cord ischemia; TEVAR, thoracic endovascular aortic repair.

Table 7 Outcomes of trials/registries in type B aortic dissection

\begin{tabular}{|c|c|c|c|c|c|c|c|}
\hline $\begin{array}{l}\text { Trial/ } \\
\text { Registry }\end{array}$ & Subclassification & $\begin{array}{l}\text { Aorta specific } \\
5 \text {-y mortality } \\
\text { rate }\end{array}$ & $\begin{array}{l}\text { FL/TL/total } \\
\text { lumen } \\
(\mathrm{mm})\end{array}$ & $\begin{array}{l}30-d \\
\text { mortality } \\
(\%)\end{array}$ & $\begin{array}{l}\text { Mean } \\
\text { follow-up } \\
\text { (y) }\end{array}$ & $\begin{array}{l}\text { Survival } \\
\text { rate }\end{array}$ & Other Comments \\
\hline $\begin{array}{l}\text { INSTEAD } \\
\text { XL trial }\end{array}$ & $\begin{array}{l}\text { Uncomplicated } \\
\text { beyond acute } \\
\text { phase }\end{array}$ & $\begin{array}{l}\text { EVAR + OMT- } \\
6.9 \% \\
\text { OMT-19.3\% }\end{array}$ & NA & & 2 & $\begin{array}{l}\text { EVAR }+ \\
\text { OMT-28.1\% } \\
\text { OMT-4.1\% }\end{array}$ & NA \\
\hline $\begin{array}{l}\text { ADSORB } \\
\text { trial }^{46}\end{array}$ & $\begin{array}{l}\text { Acute } \\
\text { uncomplicated }\end{array}$ & NA & $\begin{array}{l}\text { BMT + EVAR } \\
(1 \mathrm{y}) \\
18.5 / 32.2 / \\
38.8 \\
\text { BMT (1 y) } \\
25.1 / 25.5 / \\
42.1\end{array}$ & & 1 & NA & NA \\
\hline $\begin{array}{l}\text { VIRTUE } \\
\text { registry }\end{array}$ & $\begin{array}{l}\text { Acute } \\
\text { Subacute } \\
\text { Chronic } \\
\text { (complicated) }\end{array}$ & NA & & $\begin{array}{l}\text { Acute-8 } \\
\text { Subacute-0 } \\
\text { Chronic-0 }\end{array}$ & 3 & NA & $\begin{array}{l}\text { Acute and suba- } \\
\text { cute: greater re- } \\
\text { duction in FL area } \\
\text { than chronic } \\
\text { group } \\
\text { Acute and suba- } \\
\text { cute: consistent } \\
\text { reduction in FL } \\
\text { area } \\
\text { Chronic group: } \\
\text { overall increase in } \\
\text { FL area }\end{array}$ \\
\hline
\end{tabular}

Abbreviations: ADSORB, Acute Dissection: Stent graft OR Best medical therapy; BMT, best medical treatment; EVAR, endovascular aortic repair; FL, false lumen; INSTEAD, INvestigation of STEnt Grafts in Aortic Dissection; NA, not available; OMT, optimal medical treatment; TL, true lumen.

The premature occlusion of the false lumen entrance seems to improve the prognosis of patients in the long term. Studies have suggested that the patency of the false lumen remains an independent risk factor for death or events related to the dissection. ${ }^{48}$ The mortality associated with dissection is nearly 5.6 times lower in patients with thrombosed false sac on medical treatment than in the group of patients in whom the false lumen remained patent. Recently published data from various trials ( - Table 7 ) suggest that thrombosis of the false lumen and stabilization of the aortic diameter translate into long-term prevention of aortic rupture.

\section{Conclusion}

Overall, there is reasonable consensus that acute type A dissections should be treated by surgery and that uncomplicated type $B$ dissections should be treated with optimized medical therapy. Complicated acute type B dissections should be offered treatment by EVR in suitable patients. Surgery may be reserved for those in whom EVR is not feasible, fails, or results in a complication. Strategies for managing chronic complicated type B dissections are less clear. EVR has shown lower mortality rates, lower incidence of complications related to the aorta, and lower disease 
progression. There is evidence that EVR may be noninferior to surgery in this group of patients. Clinical and imaging markers are emerging to identify patients with uncomplicated chronic type B dissection who may have an adverse outcome following medical therapy. Current devices used for EVR are not designed for the treatment of AD and have major limitations in terms of addressing the requirements for optimal treatment goals. Overall, device designs and management algorithms in these patients are still evolving. More validated clinical data are necessary to define the role of EVR in the management of type B aortic dissections.

\section{References}

1 Elefteriades JA, Rizzo JA. Epidemiology, prevalence, incidence, trends. In: Elefteriades JA, ed. Acute Aortic Disease. New York, NY: Informa Healthcare; 2008:89-98

2 Mehta RH, Bossone E, Evangelista A, et al; International Registry of Acute Aortic Dissection Investigators. Acute type B aortic dissection in elderly patients: clinical features, outcomes, and simple risk stratification rule. Ann Thorac Surg 2004;77(05):1622-1628, discussion 1629

3 Hagan PG, Nienaber CA, Isselbacher EM, et al. The International Registry of Acute Aortic Dissection (IRAD): new insights into an old disease. JAMA 2000;283(07):897-903

4 Cerna M, Kocher M, Thomas RP. Acute aorta, overview of acute CT findings and endovascular treatment options. Biomed Pap Med Fac Univ Palacky Olomouc Czech Repub 2017;161(01):14-23

5 Erbel R, Alfonso F, Boileau C, et al; Task Force on Aortic Dissection, European Society of Cardiology. Diagnosis and management of aortic dissection. Eur Heart J 2001;22(18):1642-1681

6 Elefteriades JA, Farkas EA. Thoracic aortic aneurysm clinically pertinent controversies and uncertainties. J Am Coll Cardiol 2010; 55(09):841-857

7 Yuan SM. Postpartum aortic dissection. Taiwan J Obstet Gynecol 2013;52(03):318-322

8 Manfredini R, Boari B, Gallerani M, et al. Chronobiology of rupture and dissection of aortic aneurysms. J Vasc Surg 2004;40(02): 382-388

9 Muhs BE, Vincken KL, van Prehn J, et al. Dynamic cine-CT angiography for the evaluation of the thoracic aorta; insight in dynamic changes with implications for thoracic endograft treatment. Eur J Vasc Endovasc Surg 2006;32(05):532-536

10 Ueda T, Fleischmann D, Rubin GD, Dake MD, Sze DY. Imaging of the thoracic aorta before and after stent-graft repair of aneurysms and dissections. Semin Thorac Cardiovasc Surg 2008;20(04):348-357

11 Nienaber CA, Eagle KA. Aortic dissection: new frontiers in diagnosis and management: Part II: therapeutic management and follow-up. Circulation 2003;108(06):772-778

12 Criado FJ. Aortic dissection: a 250-year perspective. Tex Heart Inst J 2011;38(06):694-700

13 Onitsuka S, Akashi H, Tayama K, et al. Long-term outcome and prognostic predictors of medically treated acute type B aortic dissections. Ann Thorac Surg 2004;78(04):1268-1273

14 Akin I, Kische S, Ince $\mathrm{H}$, Nienaber CA. Indication, timing and results of endovascular treatment of type B dissection. Eur J Vasc Endovasc Surg 2009;37(03):289-296

15 Schneider AJ. Assessment of risk factors and surgical outcome. Surg Clin North Am 1983;63(05):1113-1126

16 Feldman M, Shah M, Elefteriades JA. Medical management of acute type A aortic dissection. Ann Thorac Cardiovasc Surg 2009; 15(05):286-293

17 Walsh SR, Tang TY, Sadat U, et al. Endovascular stenting versus open surgery for thoracic aortic disease: systematic review and meta-analysis of perioperative results. J Vasc Surg 2008;47(05): 1094-1098
18 Coady MA, Rizzo JA, Hammond GL, Kopf GS, Elefteriades JA. Surgical intervention criteria for thoracic aortic aneurysms: a study of growth rates and complications. Ann Thorac Surg 1999; 67(06):1922-1926, discussion 1953-1958

19 Dake MD, Miller DC, Semba CP, Mitchell RS, Walker PJ, Liddell RP. Transluminal placement of endovascular stent-grafts for the treatment of descending thoracic aortic aneurysms. N Engl J Med 1994;331(26):1729-1734

20 Xiong J, Jiang B, Guo W, Wang SM, Tong XY. Endovascular stent graft placement in patients with type $B$ aortic dissection: a meta-analysis in China. J Thorac Cardiovasc Surg 2009;138(04):865-872

21 Fann JI, Smith JA, Miller DC, et al. Surgical management of aortic dissection during a 30-year period. Circulation 1995;92(9, Suppl): II113-II121

22 Duarte JJ, Pontes JC, Benfatti RA, Ferrachini AL, Karakhanian WK, Razuk Filho A. Indication of endovascular treatment of type B aortic dissection-literature review. Rev Bras Cir Cardiovasc 2014; 29(03):396-401

23 Jonker FH, Trimarchi S, Verhagen HJ, Moll FL, Sumpio BE, Muhs BE. Meta-analysis of open versus endovascular repair for ruptured descending thoracic aortic aneurysm. J Vasc Surg 2010;51(04): 1026-1032, 1032.e1-1032.e2

24 Nienaber CA, Rousseau H, Eggebrecht H, et al; INSTEAD Trial. Randomized comparison of strategies for type B aortic dissection: the INvestigation of STEnt Grafts in Aortic Dissection (INSTEAD) trial. Circulation 2009;120(25):2519-2528

25 Parsa CJ, Schroder JN, Daneshmand MA, McCann RL, Hughes GC. Midterm results for endovascular repair of complicated acute and chronic type B aortic dissection. Ann Thorac Surg 2010;89(01): 97-102, discussion 102-104

26 Eggebrecht H, Nienaber CA, Neuhäuser M, et al. Endovascular stent-graft placement in aortic dissection: a meta-analysis. Eur Heart J 2006;27(04):489-498

27 Evangelista A, Salas A, Ribera A, et al. Long-term outcome of aortic dissection with patent false lumen: predictive role of entry tear size and location. Circulation 2012;125(25):3133-3141

28 Kitada S, Akutsu K, Tamori Y, Yoshimuta T, Hashimoto H, Takeshita S. Usefulness of fibrinogen/fibrin degradation product to predict poor one-year outcome of medically treated patients with acute type B aortic dissection. Am J Cardiol 2008;101(09):1341-1344

29 Luebke T, Brunkwall J, Type B. Type B aortic dissection: a review of prognostic factors and meta-analysis of treatment options. Aorta (Stamford) 2014;2(06):265-278

30 Jonker FH, Trimarchi S, Rampoldi V, et al; International Registry of Acute Aortic Dissection (IRAD) Investigators. Aortic expansion after acute type B aortic dissection. Ann Thorac Surg 2012;94(04): 1223-1229

31 Tolenaar JL, van Keulen JW, Jonker FH, et al. Morphologic predictors of aortic dilatation in type B aortic dissection. J Vasc Surg 2013;58(05):1220-1225

32 Clough RE, Albayati MA, Donati T, Taylor PR. Uncomplicated type B dissections: which patients should be treated? Lessons learned from the recent literature. J Cardiovasc Surg (Torino) 2014;55(02, Suppl 1):145-150

33 Grommes J, Greiner A, Bendermacher B, et al. Risk factors for mortality and failure of conservative treatment after aortic type $B$ dissection. J Thorac Cardiovasc Surg 2014;148(05):2155-2160.e1

34 Tsai TT, Evangelista A, Nienaber CA, et al; International Registry of Acute Aortic Dissection. Partial thrombosis of the false lumen in patients with acute type B aortic dissection. N Engl J Med 2007; 357(04):349-359

35 Song JM, Kim SD, Kim JH, et al. Long-term predictors of descending aorta aneurysmal change in patients with aortic dissection. J Am Coll Cardiol 2007;50(08):799-804

36 Loewe C, Czerny M, Sodeck GH, et al. A new mechanism by which an acute type B aortic dissection is primarily complicated, becomes complicated, or remains uncomplicated. Ann Thorac Surg 2012;93(04):1215-1222 
37 Kitamura T, Torii S, Oka N, et al. Key success factors for thoracic endovascular aortic repair for non-acute Stanford type B aortic dissection. Eur J Cardiothorac Surg 2014;46(03):432-437, discussion 437

38 Fattori R, Cao P, De Rango P, et al. Interdisciplinary expert consensus document on management of type $\mathrm{B}$ aortic dissection. J Am Coll Cardiol 2013;61(16):1661-1678

39 Fattori R, Tsai TT, Myrmel T, et al. Complicated acute type B dissection: is surgery still the best option? A report from the International Registry of Acute Aortic Dissection. JACC Cardiovasc Interv 2008;1(04):395-402

40 Trimarchi S, Eagle KA, Nienaber CA, et al; International Registry of Acute Aortic Dissection (IRAD) Investigators. Importance of refractory pain and hypertension in acute type B aortic dissection: insights from the International Registry of Acute Aortic Dissection (IRAD). Circulation 2010;122(13):1283-1289

41 Leurs LJ, Bell R, Degrieck Y, Thomas S, Hobo R, Lundbom J; EUROSTAR; UK Thoracic Endograft Registry collaborators. Endovascular treatment of thoracic aortic diseases: combined experience from the EUROSTAR and United Kingdom Thoracic Endograft registries. J Vasc Surg 2004;40(04):670-679, discussion 679-680

42 Fattori R, Montgomery D, Lovato L, et al. Survival after endovascular therapy in patients with type B aortic dissection: a report from the International Registry of Acute Aortic Dissection (IRAD). JACC Cardiovasc Interv 2013;6(08):876-882
43 Zeeshan A, Woo EY, Bavaria JE, et al. Thoracic endovascular aortic repair for acute complicated type B aortic dissection: superiority relative to conventional open surgical and medical therapy. J Thorac Cardiovasc Surg 2010;140(6, Suppl):S109-S115, discussion S142-S146

44 Nienaber $\mathrm{CA}$, Kische $\mathrm{S}$, Rousseau $\mathrm{H}$, et al; INSTEAD-XL trial. Endovascular repair of type $B$ aortic dissection: long-term results of the randomized investigation of stent grafts in aortic dissection trial. Circ Cardiovasc Interv 2013;6(04):407-416

45 Garbade J, Jenniches M, Borger MA, et al. Outcome of patients suffering from acute type $B$ aortic dissection: a retrospective single-centre analysis of 135 consecutive patients. Eur J Cardiothorac Surg 2010;38(03):285-292

46 Brunkwall J, Kasprzak P, Verhoeven E, et al; ADSORB Trialists. Endovascular repair of acute uncomplicated aortic type $B$ dissection promotes aortic remodelling: 1 year results of the ADSORB trial. Eur J Vasc Endovasc Surg 2014;48(03): 285-291

47 VIRTUE Registry Investigators. Mid-term outcomes and aortic remodelling after thoracic endovascular repair for acute, subacute, and chronic aortic dissection: the VIRTUE Registry. Eur J Vasc Endovasc Surg 2014;48(04):363-371

48 Akutsu K, Nejima J, Kiuchi K, et al. Effects of the patent false lumen on the long-term outcome of type B acute aortic dissection. Eur J Cardiothorac Surg 2004;26(02):359-366 